\title{
Transcatheter implantation of the biological Sapien Edwards valve in the pulmonary position - first experiences
}

Przeznaczyniowe wszczepienie biologicznej zastawki Sapien Edwards w pozycję płucną pierwsze doświadczenia

\author{
Marcin Demkow ${ }^{1}$, Witold Rużyłło', Elżbieta Katarzyna Biernacka², Mirosław Kowalski², Mateusz Śpiewak², \\ Göran Olivecrona ${ }^{3}$, Piotr Hoffman ${ }^{2}$ \\ 1Department of Coronary Artery Disease and Structural Heart Diseases, Institute of Cardiology, Warsaw, Poland \\ 2Department of Congenital Heart Diseases, Institute of Cardiology, Warsaw, Poland \\ 3Department of Cardiology, Skane University Hospital, Lund, Sweden
}

Post Kardiol Interw 2011; 7, 2 (24): 111-115 DOI: $10.5114 /$ pwki.2011.23162

\begin{abstract}
We present the first in Poland, and among the first in Europe, cases of transcatheter implantation of the biological Sapien Edwards valve in the pulmonary position. The valves were implanted successfully without periprocedural complications in 2 patients with postoperative right ventricular outflow tract dysfunction.
\end{abstract}

Key words: transcatheter pulmonary valve implantation, Sapien Edwards valve

\section{Streszczenie}

Przedstawiono pierwsze w Polsce i jedne z pierwszych w Europie przypadki przezcewnikowego wszczepienia biologicznej zastawki Sapien Edwards w pozycję płucną. Zastawki wszczepiono skutecznie i bez powikłań u 2 pacjentów z pooperacyjną dysfunkcją drogi odpływu prawej komory.

Słowa kluczowe: przezcewnikowe wszczepienie zastawki płucnej, zastawka Sapien Edwards

\section{Introduction}

Transcatheter implantation of a pulmonary valve has been performed since the year 2000 [1]. Candidates for this procedure include patients after a surgical correction of a heart defect using a pulmonary homograft connecting the right ventricular outflow tract and pulmonary artery in whom homograft dysfunction due to its degenerative changes has occurred. A Medtronic Melody biological valve used for that indication may be implanted only in patients with a relatively narrow right ventricular outflow tract because of its dimension (maximally $22 \mathrm{~mm}$ ) [2]. The biological Sapien Edwards valve routinely used for transcatheter aortic valve implantation (TAVI) was implanted in the pulmonary position for the first time in 2006 [3, 4]. The sizes of this valve $(23 \mathrm{~mm}$ and $26 \mathrm{~mm})$ permit its implantation in patients with a wider right outflow tract in comparison to the Melody valve. Below we present the first in Poland and among the first in Europe cases of transcatheter implantation of a biological Sapien Edwards valve in the pulmonary position. The procedures were performed on April 29th, 2011.

\section{The valve}

The biological Sapien Edwards valve (Edwards Lifesciences LLC, Irvine, CA, USA) is routinely used for transcatheter aortic valve implantation (fig. 1). It consists of three leaflets made from bovine pericardium and installed on a self-expandable steel stent. The pericardium undergoes special processing (Thermafix TM anti-calcification treatment) used for surgical Carpentier-Edwards valves. The valve is available in two diameters $-23 \mathrm{~mm}$ and $26 \mathrm{~mm}$.

Corresponding author/Adres do korespondencji:

prof. dr hab. n. med. Marcin Demkow, Klinika Choroby Wieńcowej i Strukturalnych Chorób Serca, Instytut Kardiologii, ul. Alpejska 42, 04-628 Warszawa, Polska, tel.: +48 2232323 42, faks: +48 22343 45 16, e-mail: mdemkow@ikard.pl

Praca wpłynęła: 2.06.2011, przyjęta do druku: 10.06.2011. 


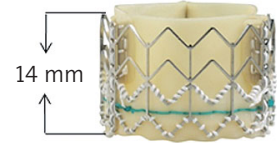

$23 \mathrm{~mm}$ Sapien

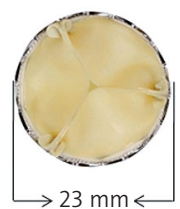

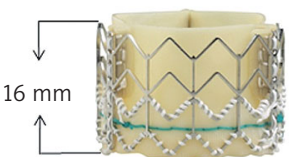

26 mm Sapien

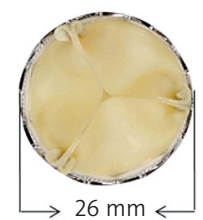

Fig. 1. Biological Sapien Edwards valve

Ryc. 1. Zastawka biologiczna Sapien Edwards

\section{Heart catheterization and the procedure}

The procedure was performed from the right femoral access under general anaesthesia with intratracheal intubation. The implantation was preceded by right heart catheterization with complete haemodynamic and anatomical assessment of the right ventricular tract, pulmonary trunk and pulmonary arteries. Selective coronary angiography was performed with particular attention to the localization of arteries in relation to the planned site of valve implantation to exclude the risk of coronary artery compression by the expanded valve [5]. Coronary angiography was accompanied by simultaneous expansion of the bal-

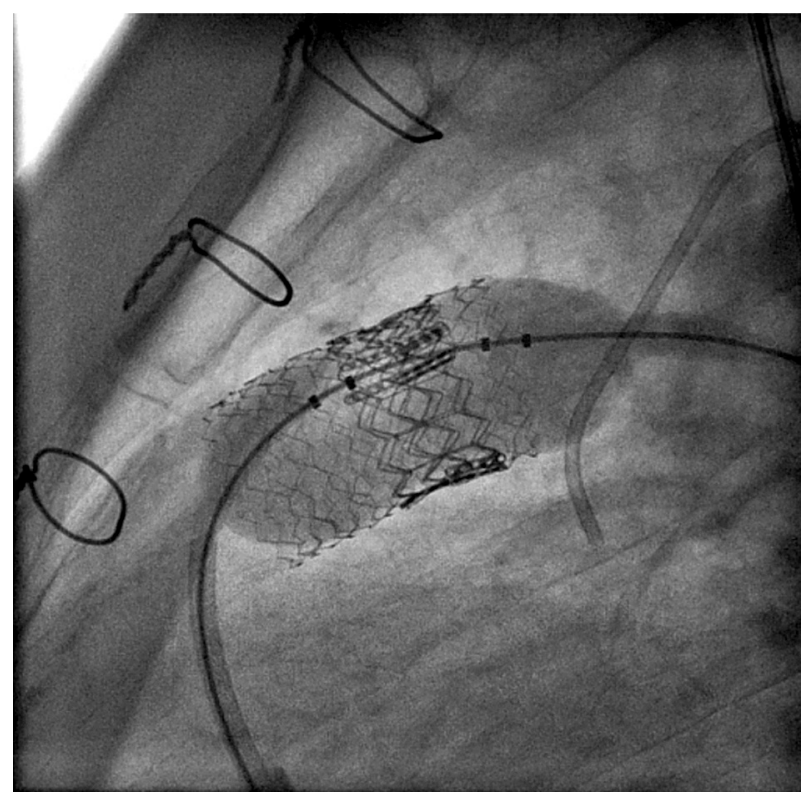

Fig. 2. The moment of Sapien Edwards valve implantation in the pulmonary position (expanded balloon with installed valve)

Ryc. 2. Moment wszczepienia zastawki Sapien Edwards w pozycji płucnej (rozprężony balon z zamontowana zastawka) loon in the right ventricular outflow tract followed by detailed measurements of that area. The procedure was done in two steps. At first a metal stent (IntraStent Max LD, ev3 Endovascular Plymouth, USA) of 1-3 mm smaller diameter in comparison to the planned valve was delivered on the balloon in the future valve position. Then a Retroflex III system with 23 or $26 \mathrm{~mm}$ balloon was used to introduce the valve in the pulmonary position. The valve was installed on the balloon using a specially supplied "clamper" and introduced on a delivery system through a $22 \mathrm{~F}$ or $24 \mathrm{~F}$ sheath on a rigid guide-wire with a tip placed deep in one of the pulmonary branches. Heparin and one dose of antibiotic (cephalosporin) were administered during the procedure. After the procedure haemostasis was obtained by a single intradermal suture (figs. 2-4).

\section{Case reports}

\section{Case 1}

A 47-year-old patient with a tetralogy of Fallot, after a palliative Blalock-Taussig shunt in 1970 followed by complete correction in 1977, after reoperation consisting of closure of a re-canalized interventricular septal defect, pulmonary homograft implantation and tricuspid valve plasty in 1999, after radiofrequency ablation of the substrate of atrial tachycardia in 2008 was admitted because of significant pulmonary valve regurgitation with moderate stenosis. Despite good physical condition, physical examination revealed oedema of the lower extremities and systolic ejection murmur as well as diastolic murmur most pronounced

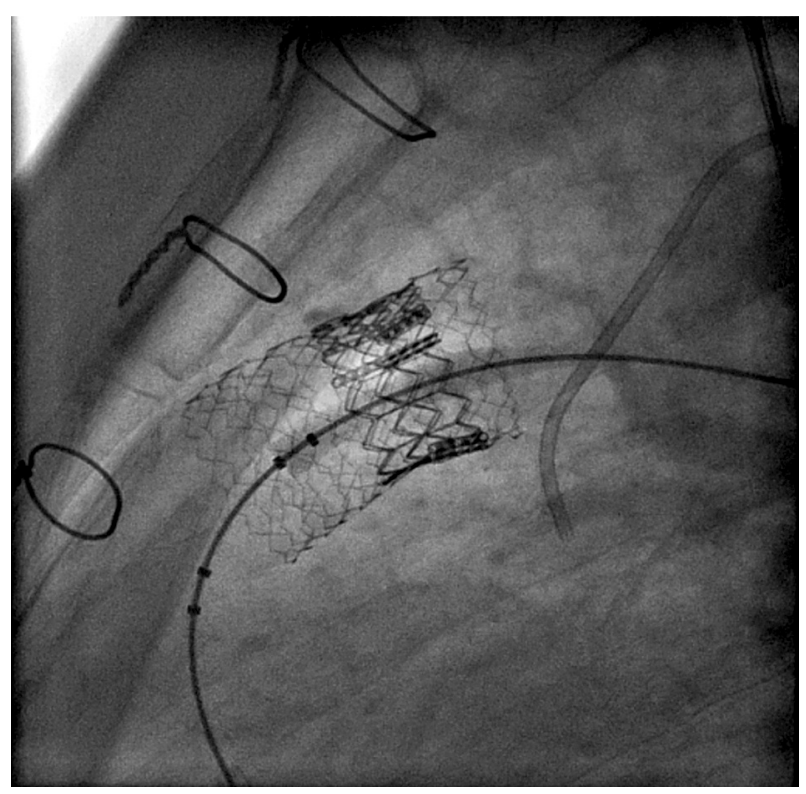

Fig. 3. Radiological image of the valve stent implanted in the right ventricular outflow tract Ryc. 3. Obraz radiologiczny stentu zastawki wszczepionej $w$ drogę odptywu prawej komory 
over the site of pulmonary. The pulmonary trunk was hardly visualized on the echocardiographic examination. The transpulmonary valve gradient of $80 \mathrm{mmHg}$ was measured. There was a significant pulmonary regurgitation and a moderate tricuspid regurgitation. An magnetic resonance imaging (MRI) examination showed marked dilation of the right ventricle $\left(E D V / B S A\left(\mathrm{ml} / \mathrm{m}^{2}\right)=176, \mathrm{~N}: 67-111\right)$ with decreased global ejection fraction (EF (\%) = 37, N: 49-73) and increased muscle mass (right ventricular wall thickness of 7-8 mm). There were also signs of increased right ventricular pressure and dilation of the inferior vena cava and hepatic veins. The dimensions of the pulmonary trunk assessed at the level of the pulmonary valve (obtained from the 3D reconstruction of the magnetic resonance angiography) were $16 \times 26 \mathrm{~mm}$ (mean $20 \mathrm{~mm}$ ). Transcatheter pulmonary valve implantation of an Sapien Edwards $23 \mathrm{~mm}$ valve was performed on 29.04.2011. Pulmonary valve implantation was preceded by the implantation of an additional stent using a BIB $22 \mathrm{~mm}$ balloon. A control echocardiographic examination performed on the second day after the procedure showed small valve regurgitation with discrete perivalvular leaks; maximal transpulmonary valve gradient was $37 \mathrm{mmHg}$, mean $23 \mathrm{mmHg}$. The patient was discharged home in a good general condition on the $3^{\text {rd }}$ day after the procedure.

\section{Case 2}

A 22-year-old patient after complete correction of the tetralogy of Fallot accompanied by right ventricular outflow tract reconstruction with a patch (pulmonary "monocusp" type) in the $3^{\text {rd }}$ year of life was admitted to the hospital because of severe pulmonary regurgitation. She had complained of exercise intolerance for 2 years. Imaging tests showed a severe regurgitant pulmonary wave (pulmonary regurgitant fraction [PRF] on magnetic resonance imaging was $49 \%)$ and dilated right ventricle (EDV/BSA $\left(\mathrm{ml} / \mathrm{m}^{2}\right)$ $=144, \mathrm{~N}: 65-102$ ) with preserved right ventricular ejection fraction (EF 52\%). The dimensions of the pulmonary trunk at the level of the pulmonary valve (obtained from the 3D reconstruction of the magnetic resonance angiography) were $15 \times 20 \mathrm{~mm}$ (mean $17 \mathrm{~mm}$ ), with dynamic changes throughout the heart cycle. Maximal dimension of the valve was $17 \times 20 \mathrm{~mm}$. Susceptibility of the right ventricular outflow tract was assessed before the transcatheter pulmonary valve implantation with a high-pressure Mullins X $22 \mathrm{~mm}$ balloon. A balloon of $22 \mathrm{~mm}$ diameter did not show a waistline after full inflation (the site of stenosis was extended with very low pressures) (figs. 5, 6). It was decided that the anatomy of the outflow tract did not permit Melody valve implantation. After a few months a transvenous pulmonary Sapien Edwards valve $(26 \mathrm{~mm})$ was implanted. Before the procedure the size of the right ventricular outflow tract and pulmonary trunk were assessed with a $30 \mathrm{~mm}$ balloon. The diameter at the narrowest place was $20 \mathrm{~mm}$. Valve implantation was preceded by stent implantation on the BIB

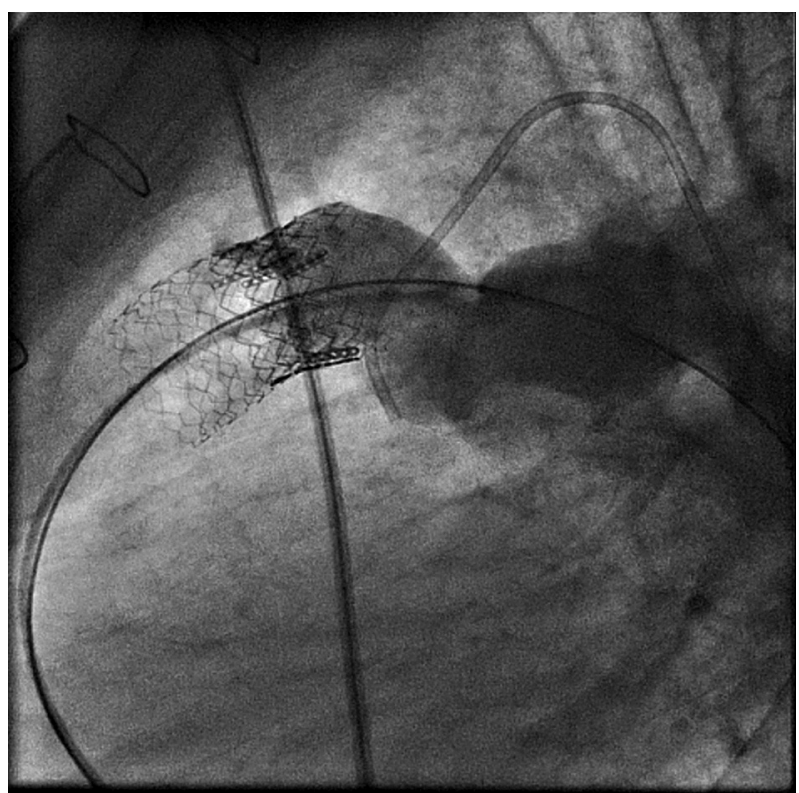

Fig. 4. Contrast medium injected into the pulmonary artery does not flow back into the right ventricle - there is no valvular or perivalvular leak and there is a wide ventricular outflow tract. The new valve functions properly

Ryc. 4. Kontrast podany do tętnicy płucnej nie cofa się do prawej komory - zastawka jest szczelna, a droga wyptywu krwi z komory szeroka. Nowa zastawka płucna funkcjonuje prawidłowo

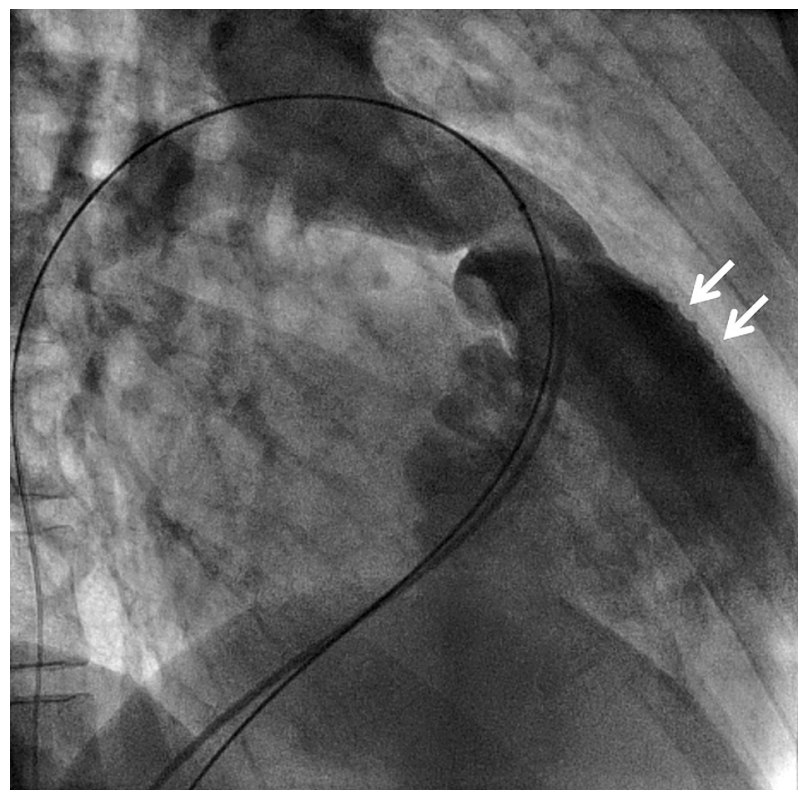

Fig. 5. Patient 2. Pulmonary angiography in RAO projection. Severe pulmonary incompetence. The outflow patch is indicated by the arrow

Ryc. 5. Pacjent 2. Angiografia płucna, projekcja w prawym skosie. Bardzo duża niedomykalność płucna. W drodze odptywu prawej komory widoczna tata (strzatka) 


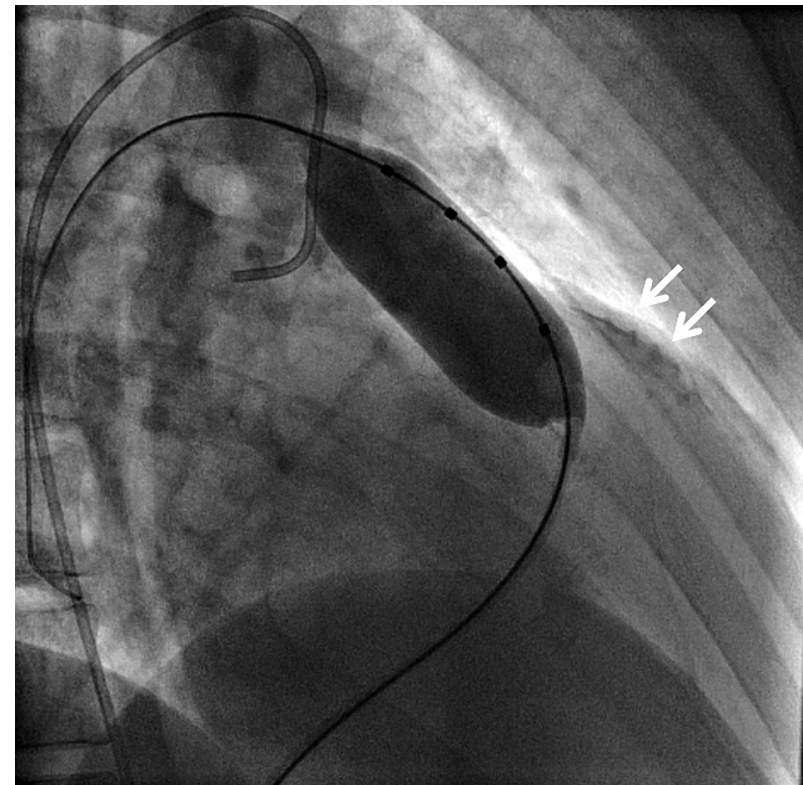

Fig. 6. Patient 2. Same projection as in fig. 5. A 22 $\mathrm{mm}$ balloon shows no indentation at full inflation. The outflow patch is indicated by the arrow Ryc. 6. Pacjent 2. Ta sama projekcja jak na ryc. 5. Balon o średnicy $22 \mathrm{~mm}$ przy petnym wypetnieniu nie wykazuje talii (miejsce zwężenia ulegało rozciągnięciu przy matych ciśnieniach). W drodze odpływu prawej komory widoczna łata (strzatka)

$24 \mathrm{~mm}$ balloon. Echocardiographic examination performed on the day following the procedure showed traces of pulmonary regurgitation and a transpulmonary valve gradient of $26 / 12 \mathrm{mmHg}$. The patient was discharged home on the $3^{\text {rd }}$ day after the procedure.

\section{Discussion}

Transcatheter pulmonary valve implantation is an alternative to previously used surgery. It is less invasive, with a lower periprocedural risk (especially in a patient after a few surgical interventions) and with a much shorter hospital stay, which is of high significance in active patients such as most patients after congenital heart surgery. Late pulmonary valve dysfunction is a very common problem in patients after surgery including reconstruction of the right ventricular tract. The most numerous group consists of patients after correction of tetralogy of Fallot, pulmonary atresia, and Rastelli or Ross procedures. Conduits used for the reconstruction (usually pulmonary homografts, less frequently xenografts (Contegra) or aortic homografts) undergo degeneration in the course of several years which leads to right ventricular outflow tract stenosis. Ventricular outflow tract reconstruction using a transannular patch or a "monocusp" valve causes pulmonary regurgitation even directly after the procedure. In patients with right ventricular outflow tract dysfunction very good results are obtained after Melody valve implantation [2, 6]. A major limitation of this method is the size of the valve, as it may be maximally expanded to $22 \mathrm{~mm}$. In most patients with a transannular patch used for the reconstruction as well as in many patients with pulmonary homograft the dimensions of the right ventricular tract are larger and therefore exclude the use of a Melody valve. The valve used for transcatheter aortic valve implantation was implanted in the pulmonary position for the first time in 2006 [3]. Experiences with this type of valve in the pulmonary position are scarce and limited to descriptions of a few cases after correction with the pulmonary homograft, mostly with predominant stenosis [7, 8]. The procedures performed in the Institute of Cardiology on 29.04.2011 are among the first in Europe. In the case of the second patient the Sapien Edwards valve was implanted into the right ventricular outflow tract reconstructed with a transannular patch (with a "monocusp" pulmonary valve). So far there are only a few described cases of transcatheter pulmonary valve implantation in patients without a complete conduit (with the native right ventricular outflow tract or with a transannular patch): this was the Melody valve in 6 cases $[2,6]$. So far there is only one described case of SE valve implantation into the native outflow tract. The procedure was performed in a 26-year-old female patient with pulmonary atresia, after surgical pulmonary valvulotomy, with severe pulmonary regurgitation, in whom a poor clinical condition enabled the surgical approach. The transcatheter procedure was performed in two steps - the valve was implanted a few months after the implantation of a metal stent [9]. The SE valves create a possibility for transcatheter treatment in patients with a wider right ventricular outflow tract in comparison to those qualified for Melody valve implantation. The KW case shows that this type of valve may also be used in selected patients without a complete conduit in the right ventricular outflow tract. This is extremely important as pulmonary regurgitation is most often present in patients with a transannular patch [8].

\section{References}

1. Bonhoeffer P, Boudjemline Y, Saliba Z, et al. Percutaneous replacement of pulmonary valve in a right-ventricle to pulmonaryartery prosthetic conduit with valve dysfunction. Lancet 2000; 356; 1403-1405.

2. Lurz P, Coats L, Khambadkone S, et al. Percutaneous pulmonary valve implantation. Impact of evolving technology and learning curve on clinical outcome. J Am Coll Cardiol 2009; 53: 1859-1863.

3. Garay F, Webb J, Hijazi ZM. Percutaneous replacement of pulmonary valve using the Edwards-Cribier percutaneous heart valve: first report in a human patient. Catheter Cardiovasc Interv 2006; 67: 659-662.

4. Webb JG, Munt B, Makkar RR, et al. Percutaneous stent-mounted valve for treatment of aortic or pulmonary valve disease. Catheter Cardiovasc Interv 2004; 63: 89-93.

5. Sridharan S, Coats L, Khambadkone S, et al. Transcatheter right ventricular tract intervention: the risk of coronary circulation. Circulation 2006; 113: e934-e935. 
6. Biernacka EK, Demkow M, Śpiewak M, et al. Early and one year results of transvascular pulmonary valve implantation in patients after tetralogy of Fallot, Ross and Rastelli operations. Post Kardiol Interw 2010; 6: 104-111.

7. Boone RH, Webb JG, Horlick E, et al. Transcatheter pulmonary valve implantation using the Edwards SAPIEN transcatheter heart valve. Catheter Cardiovasc Interv 2010; 75: 286-294.
8. Ewert P, Horlick E, Berger F. First implantation of the CE-marked transcatheter Sapien pulmonic valve in Europe. Clin Res Cardiol 2011; 100: 85-87.

9. Bertels RA, Blom NA, Schalij MJ. Edwards SAPIEN transcatheter heart valve in native pulmonary valve position. Heart 2010; 96 : 661. 